\title{
Improved electrochemical oxidative degradation of Reactive Red 24 dye by BDD anodes coupled with nitrate: operating parameters, kinetics, and degradation pathways
}

\section{Yining Tang \\ Hunan University \\ Yanni Guo \\ Hunan University \\ Jun Shang \\ Hunan University \\ Lei Zhou \\ Hunan University \\ Rong Pan \\ Hunan University \\ Wei Dong \\ Hunan University \\ Mengli Liu \\ Hunan University}

Deliang He ( $\sim$ lab223@163.com )

Hunan University https://orcid.org/0000-0001-6928-0686

\section{Research Article}

Keywords: EAOP, EO, Nitrate, Azo dye wastewater, RR24, BDD electrode

Posted Date: July 29th, 2021

DOI: https://doi.org/10.21203/rs.3.rs-761055/v1

License: @ (i) This work is licensed under a Creative Commons Attribution 4.0 International License. Read Full License 
Abstract: The electrochemical oxidation (EO) process coupled with BDD anode and nitrate was used to improve Reactive Red 24 (RR24) removal efficiency in wastewater treatment. The effects of operating parameters on the decolorization efficiency of RR24 were discussed, and the optimal operating parameters were obtained as follows: $45 \mathrm{~mA} \mathrm{~cm}{ }^{-2}, 100 \mathrm{mM} \mathrm{SO}_{4}{ }^{2-}, 7 \mathrm{mM} \mathrm{NO}_{3}{ }^{-}, 60^{\circ} \mathrm{C}, \mathrm{pH} 5.88$, and $100 \mathrm{mg} \mathrm{L}^{-1} \mathrm{RR} 24$ initial concentration. The energy consumption for $100 \%$ decolorization within $15 \mathrm{~min}$ is $0.92 \mathrm{kWh} \mathrm{m}^{-3}$, and the total organic carbon (TOC) reaches $51.35 \%$ within $90 \mathrm{~min}$. Through the effect of quenchers on RR24 decolorization efficiency, various active species in the $\mathrm{EO}$ process were studied. It was found that $\bullet \mathrm{OH}$ was closely related to the decolorization degradation of RR24, reaching a contribution rate of $99.47 \%$. Finally, we propose the degradation pathways of RR24 by UV-Vis spectrum and LC-MS test. In summary, the proposed treatment process could be applied to treat RR24 dyes as an efficient method.

Keywords: EAOP; EO; Nitrate; Azo dye wastewater; RR24; BDD electrode.

\section{Introduction}

There are many kinds of dyes, allowing for a colorful world in people's lives and producing huge economic benefits. At the same time, a large amount of dye wastewater is discharged into the environmental water, reducing the transparency and oxygen content of the water body and affecting the growth of aquatic organisms and microorganisms. Azo dyes are primary used in the printing and dyeing industries, accounting for more than 

dye, Reactive Red 24 (RR24) is widely used in the printing and dyeing industries because of its strong chromaticity stability and easy production. Unfortunately, RR24 is difficult to degrade, remains in the water for a long time, and has a greater hidden danger of environmental pollution (Brillas and Martinez-Huitle, 2015). Therefore, an environmentally friendly way for RR24 treatment is necessary.

In recent years, traditional physicochemical and biological treatment methods have been adopted in dye wastewater treatment. However, these technologies have some unavoidable disadvantages (Brillas and Martinez-Huitle, 2015). For example, physical adsorption produces a lot of sludge, which brings secondary pollution; although biodegradation has good prospects, the degradation of macromolecules is more complex, the retention time is extended, and the decolorization efficiency is low (Moussa et al., 2017). Thus, the transfer and indirectly oxidize organic pollutants on the anode surface by electrochemical active substances (such as $\bullet \mathrm{OH}$ ) and improves oxidation efficiency (Florenza et al., 2014; He et al., 2015). Therefore, a suitable anode material in the EAOP is critical. 
parameters, such as current density, supporting electrolyte and concentration, solution $\mathrm{pH}$, temperature, and pollutant concentration (Kuchtova et al., 2020). However, to improve the degradation efficiency of single electrochemical oxidation (EO), high current density and extended electrolysis time are usually adopted, which limiting its promotion and application in the industry, as shown in Table 1.

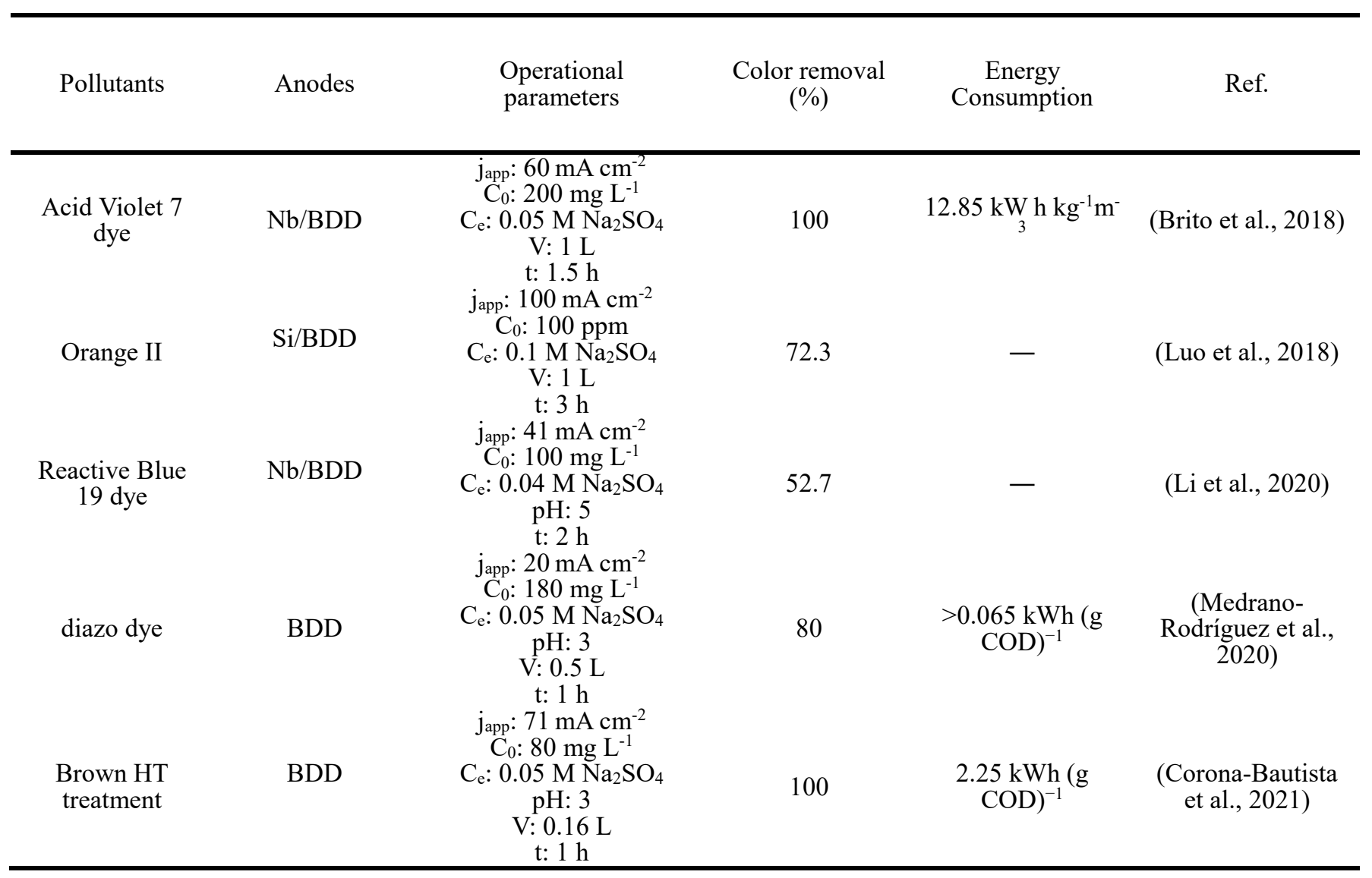
of the single EO method. (He et al., 2019; Vasconcelos et al., 2019). However, ozone and PDS directly impact human health, and hydrogen peroxide's transportation and storage costs are high. It is necessary to find an efficient and environmentally friendly combined oxidation technology to degrade dye wastewater. $\mathrm{NO}_{3}{ }^{-}$has attracted our attention because it is an oxidative oxyacid salt with specific oxidizing properties, and $\mathrm{NO}_{3} \bullet$ can also react with ionic compounds to form secondary free radicals, such as $\mathrm{SO}_{4} \bullet^{\bullet}$ (Umschlag et al., 2002; Wang 
and $\mathrm{Qu}, 2006)$. Moreover, there is still no work on adding $\mathrm{NO}_{3}{ }^{-}$as a catalyst to the $\mathrm{SO}_{4}{ }^{2-}$ solution for $\mathrm{EO}$ synergistic treatment to improve the degradation effect of simulated wastewater $\mathrm{RR} 24$. Therefore, $\mathrm{NO}_{3}{ }^{-}$was considered adding to the EO system.

\section{Materials and methods}

\subsection{Materials and chemicals}

RR24 (molecular formula $\mathrm{C}_{26} \mathrm{H}_{17} \mathrm{ClN}_{7} \mathrm{Na}_{3} \mathrm{O}_{10} \mathrm{~S}_{3}$, more information is listed in Table SM-1), Potassium ferricyanide $\left(\mathrm{K}_{3}\left[\mathrm{Fe}(\mathrm{CN})_{6}\right]\right)$, Sodium persulfate (PS), Methanol $(\mathrm{MeOH})$, Phenol, and Tert-butanol (TBA), Coumarin, 7-hydroxycoumarin $(7 \mathrm{OHC})$, sodium perchlorate $\left(\mathrm{NaClO}_{4}\right)$, sulfuric acid $\left(\mathrm{H}_{2} \mathrm{SO}_{4}\right)$ were purchased from Shanghai Macklin Biochemical Technology Co., Ltd., Anhydrous sodium sulfate $\left(\mathrm{Na}_{2} \mathrm{SO}_{4}\right)$, potassium chloride $(\mathrm{KCl})$, sodium nitrate $\left(\mathrm{NaNO}_{3}\right)$, and sodium hydroxide $(\mathrm{NaOH})$ were purchased from Shanghai Sinopharm Chemical Reagent Co., Ltd. All water is ultra-pure water $(<0.1 \mu \mathrm{s} / \mathrm{cm})$, and all above reagents are 

Co., Ltd.

\subsection{Experiment setup and operation steps} and $\mathrm{H}_{2} \mathrm{SO}_{4}$ to adjust the $\mathrm{pH}$ (pH-3C, Shanghai, China).

\subsection{Experimental analysis method}

The color removal is calculated via the following Eq. (4) (Miao et al., 2020): free radicals' influence and contribution rate.

where $A_{0}$ and $A_{t}$ are the absorbances at time 0 and $t$ respectively.

The free radical quencher $\mathrm{MeOH}$, TBA, and phenol were added to RR24 simulated wastewater to study

The energy consumption in the degradation process of RR24 is estimated by following Eq. (5) (Uranga- 


$$
E_{\mathrm{c}}=\frac{U I t}{1000 \mathrm{~V}}
$$

where $U$ is mean voltage (V) during the electrolysis; $I$ is current (A); $t$ represents the electrolysis time (h); $V$ represents the volume of wastewater being treated $\left(\mathrm{m}^{3}\right)$.

Whether the electrochemical degradation process of RR24 satisfies the pseudo-first-order kinetics can be judged by Eq. (6) (Palma-Goyes et al., 2010):

$$
\ln \left(A_{0} / A_{t}\right)=k \times t
$$
where $A_{0}$ and $A_{t}$ are the absorbances at time 0 and $t$ respectively, and $k$ represents the apparent rate constant.

The concentration of $\bullet \mathrm{OH}$ in the $\mathrm{EO}-\mathrm{NO}_{3}{ }^{-} / \mathrm{SO}_{4}{ }^{2-}$ the system is evaluated using coumarin as a fluorescent probe (Louit et al., 2005). The $\bullet \mathrm{OH}$ can react with coumarin in a ratio of 1:1 to form highly fluorescent 7 hydroxycoumarin (7OHC). A fluorescence spectrophotometer (F-7000, China) was used to obtain a standard curve of the concentration and fluorescence intensity of $7 \mathrm{OHC}$, at an emission wavelength of $456 \mathrm{~nm}$ and an fluorescence intensity of $7 \mathrm{OHC}$, and finally calculate the concentration of $\bullet \mathrm{OH}$. et al., 2019). A Waters C18 column $(2.1 \mathrm{~mm} \times 50 \mathrm{~mm})$ was applied to $\mathrm{LC}$ analysis. The sample injection volume is $20 \mu \mathrm{L}$ through the auto-sampler. Gradient elution was carried out with $0.1 \%$ formic acid aqueous solution and

114 MA solution at a flow rate of $0.3 \mathrm{~mL} \mathrm{~min}^{-1}$. The mass spectrometer was operated in electrospray positive ionization mode $(4000 \mathrm{~V})$. The scanning range of the mass spectrometer was the first level, $50-1000 \mathrm{~m} / \mathrm{z}$. 


\subsection{Morphology and electrochemical properties of the BDD anode}
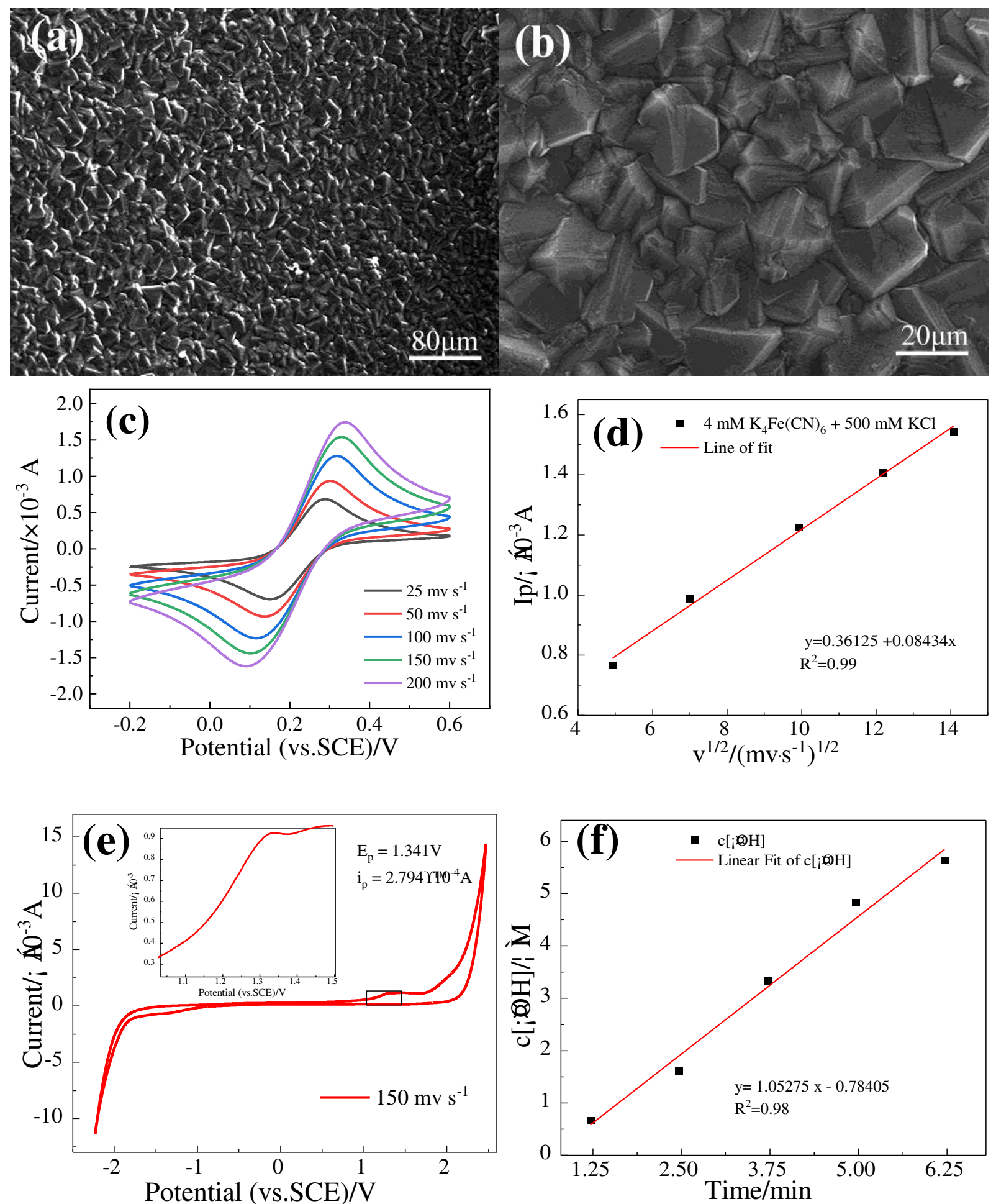

Fig. 1. SEM image of the BDD (a, b); CV curves of the BDD electrode at different scan rate (v) (c), the 
relationship curve between Ip and $v^{1 / 2}$, in $\left.0.5 \mathrm{M} \mathrm{KCl}+4 \mathrm{mM} \mathrm{K}_{4} \mathrm{Fe}(\mathrm{CN})_{6}\right)$ solution (d); The $\mathrm{CV}$ curves of the BDD in RR24 simulated wastewater at $150 \mathrm{mv} \mathrm{s}^{-1}$, the oxidation peak of RR24 (e); Variation curve of $\cdot \mathrm{OH}$ concentration on the surface of the BDD electrode with electrolysis time (f), conditions: $([\mathrm{COU}]=1 \mathrm{mM} ; j=$ $\left.20 \mathrm{~mA} \mathrm{~cm}{ }^{-2} ;\left[\mathrm{NaNO}_{3}\right]=7 \mathrm{Mm} ;\left[\mathrm{Na}_{2} \mathrm{SO}_{4}\right]=100 \mathrm{mM} ; 20^{\circ} \mathrm{C}\right)$.

Fig. 1a and $1 \mathrm{~b}$ show that the BDD film's crystal shape is large and clear, and the crystal morphology is relatively complete. In other words, BDD film is of good quality. We knew that the BDD electrode has excellent physical properties and excellent electrochemical properties. As the scan rate $(v)$ increases, the oxidation peak current (Ip) increases, and there is a good linear relationship between $v^{1 / 2}$ and Ip (Fig. 1c, and 1d), which means the diffusion process is the control step of the EO reaction. Moreover, the electrochemical window is an important indicator to measure the electrocatalytic performance of electrode material. As Fig. 1e shown that the electrochemical window of the Ti/BDD electrode is $3.50 \mathrm{~V}$, which is much larger than that of Pt or DSA electrode (El-Ghenymy et al., 2015; He et al., 2015; Soni et al., 2017). The prominent oxidation peak of RR24 near 1.34V of the CV curve proves an electron transfer reaction in the electrocatalytic process of RR24 on the BDD surface. This is evidence of the direct electrochemical oxidation of RR24. Moreover, the BDD electrode's high catalytic activity positively correlates with the $\bullet \mathrm{OH}$ produced on the surface (Panizza et al., 2001; Panizza and Cerisola, 2005). As shown in Fig.1f, the generation rate of $\cdot \mathrm{OH}$ is $1.05275 \mu \mathrm{M} \mathrm{min}^{-1}$, indicating that the BDD electrode represents a high electrocatalytic oxidation performance for RR24 (Tang et al., 2020). 

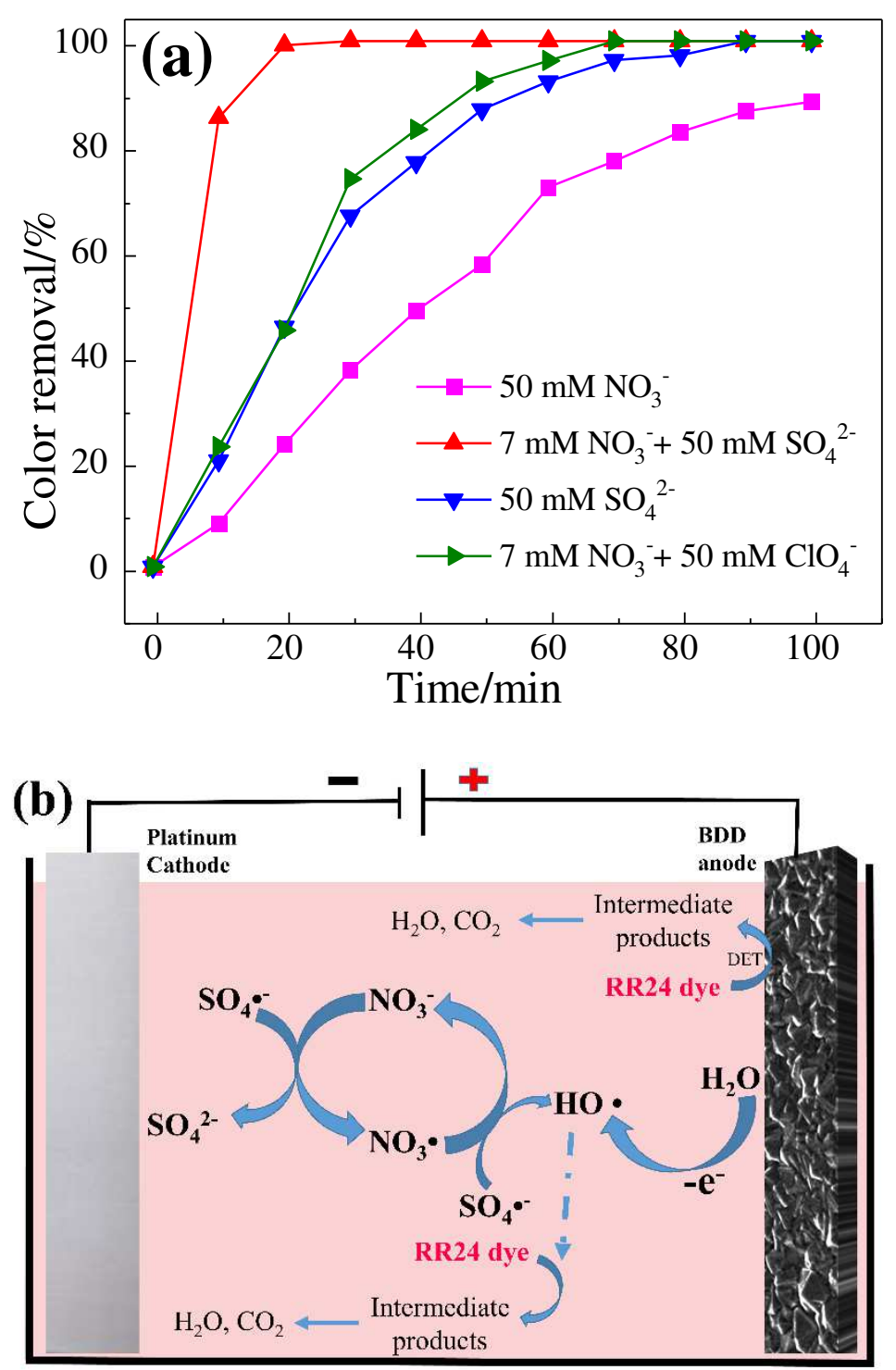

Fig. 2 The relationship curve between RR24 decolorization rate and time under different degradation system $\mathrm{mA} \mathrm{cm}{ }^{-2} ;\left[\mathrm{Na}_{2} \mathrm{SO}_{4}\right]=50 \mathrm{mM} ;[\mathrm{PS}]=5 \mathrm{mM} ;\left[\mathrm{NaClO}_{4}\right]=50 \mathrm{mM}\left[\mathrm{NaNO}_{3}\right]=50 \mathrm{mM}$, as supporting electrolyte; 

one of sulfate $\left(\mathrm{SO}_{4}^{2-}\right)$, nitrate $\left(\mathrm{NO}_{3}^{-}\right)$, and chloride (with side effects, generally not used) are used as the supporting electrolyte (Uranga-Flores et al., 2015). Fig. 2 shows that the decolorization effect of RR24 is different from the electrolysis system of different supporting electrolytes. At $30 \mathrm{~min}$, the decolorization

\subsection{The effect of operating parameters}

$$
\begin{aligned}
& \mathrm{SO}_{4} \bullet^{-}+\mathrm{NO}_{3}^{-} \rightarrow \mathrm{SO}_{4}{ }^{2-}+\mathrm{NO}_{3} \square \mathrm{k}_{1}=(5.0 \pm 0.5) \times 10^{4} \mathrm{M}^{-1} \mathrm{~s}^{-1} \\
& \mathrm{NO}_{3} \cdot+\mathrm{H}_{2} \mathrm{O} \rightarrow \cdot \mathrm{OH}+\mathrm{H}^{+} \quad \mathrm{k}_{2}=5.3 \times 10^{5} \mathrm{M}^{-1} \mathrm{~s}^{-1}
\end{aligned}
$$

\subsubsection{The effect of current density}

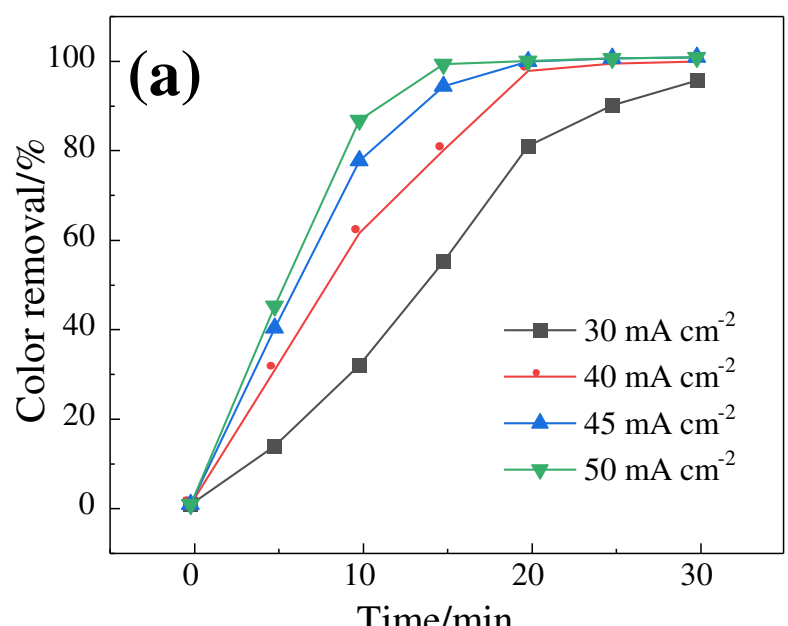

Time/min 


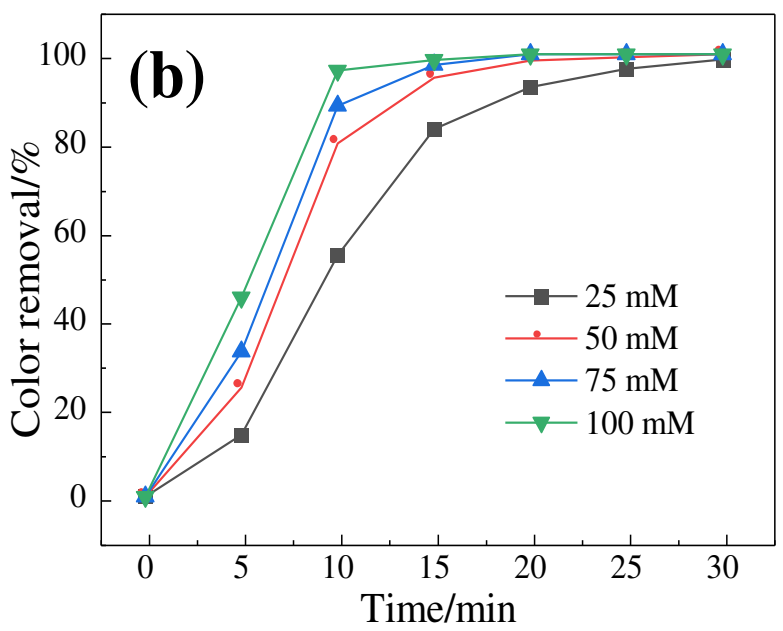

163

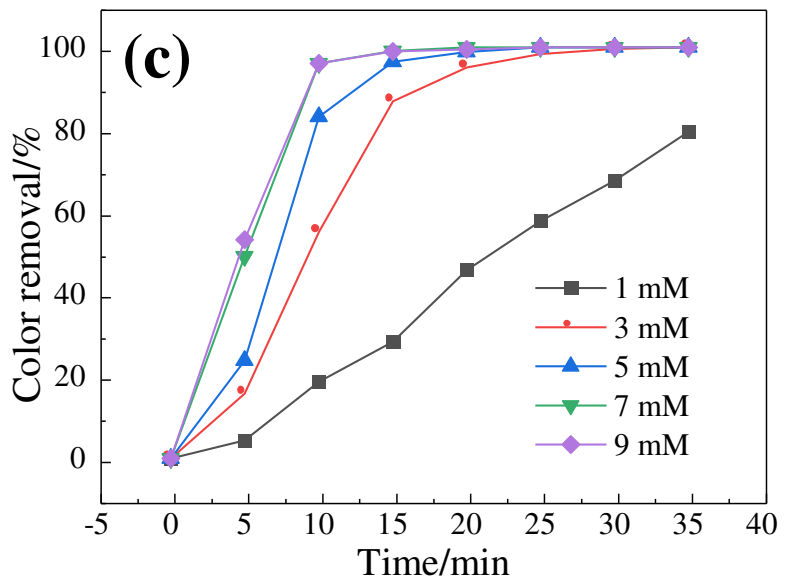

Fig. 3 Effect of current density on decolorization rate (a), conditions: $\left([\mathrm{RR} 24]=50 \mathrm{mg} \mathrm{L}^{-1} ;\left[\mathrm{Na}_{2} \mathrm{SO}_{4}\right]=50\right.$ $\mathrm{mM} ;\left[\mathrm{NaNO}_{3}\right]=5 \mathrm{mM}$; original $\left.\mathrm{pH} ; 20^{\circ} \mathrm{C}\right)$; Effect of $\mathrm{SO}_{4}{ }^{2-}$-concentration on decolorization rate (b), conditions: $\left([\mathrm{RR} 24]=50 \mathrm{mg} \mathrm{L}^{-1} ; \mathrm{j}=45 \mathrm{~mA} \mathrm{~cm}{ }^{-2} ;\left[\mathrm{NaNO}_{3}\right]=5 \mathrm{mM}\right.$; original $\left.\mathrm{pH} ; 20^{\circ} \mathrm{C}\right) ;$ Effect of $\mathrm{NO}_{3}^{-}$ concentrations on decolorization rate (c); conditions: $\left([\mathrm{RR} 24]=50 \mathrm{mg} \mathrm{L}^{-1} ; \mathrm{j}=45 \mathrm{~mA} \mathrm{~cm}{ }^{-2} ;\left[\mathrm{Na}_{2} \mathrm{SO}_{4}\right]=100\right.$

As shown in Fig. 3a, the current density has a profound impact on the degradation of RR24. At 15 min, under the current density of $30,40,45$, and $50 \mathrm{~mA} \mathrm{~cm}^{-2}$, the decolorization rates of RR24 were $54.36 \%, 79.20 \%$, $93.49 \%$, and $98.43 \%$, respectively, achieving good decolorization in a relatively short time. At 45 and $50 \mathrm{~mA}$ $\mathrm{cm}^{-2}$, the RR24 decolorization rate improves significantly, reaching almost $100 \%$ at $25 \mathrm{~min}$. In the electrolysis 
process, $\ln \left(\mathrm{A}_{0} / \mathrm{A}_{\mathrm{t}}\right)-\mathrm{t}$ accords with the pseudo-first-order kinetic relationship, and the apparent kinetic constants $k$ are $0.064 \mathrm{~min}^{-1}, 0.12 \mathrm{~min}^{-1}, 0.22 \mathrm{~min}^{-1}, 0.36 \mathrm{~min}^{-1}\left(\mathrm{R}^{2}, 0.96\right)$, respectively, which means the decolorization rate of RR24 is mainly controlled by current density. A high current density accelerates the electron transport rate;

\subsubsection{The effect of $\mathrm{NO}_{3}{ }^{-}$concentration}

The addition of $\mathrm{NO}_{3}{ }^{-}$has a significant effect on the decolorization rate of RR24 (Fig. 3c). The 

was similar. At $20 \mathrm{~min}$, the corresponding decolorization rates of $1,3,5,7,9 \mathrm{mM}$ are $28.46 \%, 86.87 \%, 96.44 \%$, $99.00 \%$, and $99.96 \%$, respectively. The addition of a small amount of $\mathrm{NO}_{3}{ }^{-}$can greatly improve the decolorization efficiency of the EO process. Moreover, $\ln \left(\mathrm{A}_{0} / \mathrm{A}_{\mathrm{t}}\right)-\mathrm{t}$ accords with the pseudo-first-order kinetic relationship in the electrolysis process. The ratio of the apparent kinetic constant is about 1:4:5:8:8 when $\mathrm{NO}_{3}{ }^{-}$ concentration is $1,3,5,7,9 \mathrm{mM}$. It shows that $\mathrm{NO}_{3}{ }^{-}$can enhance $\bullet \mathrm{OH}$ generation rate, thereby increasing the apparent kinetic constant of decolorization during the degradation process (Li et al., 2019; Ding et al., 2020). Therefore, $\mathrm{NO}_{3}{ }^{-}$concentration is $7 \mathrm{mM}$.

\subsubsection{The effect of different temperatures}
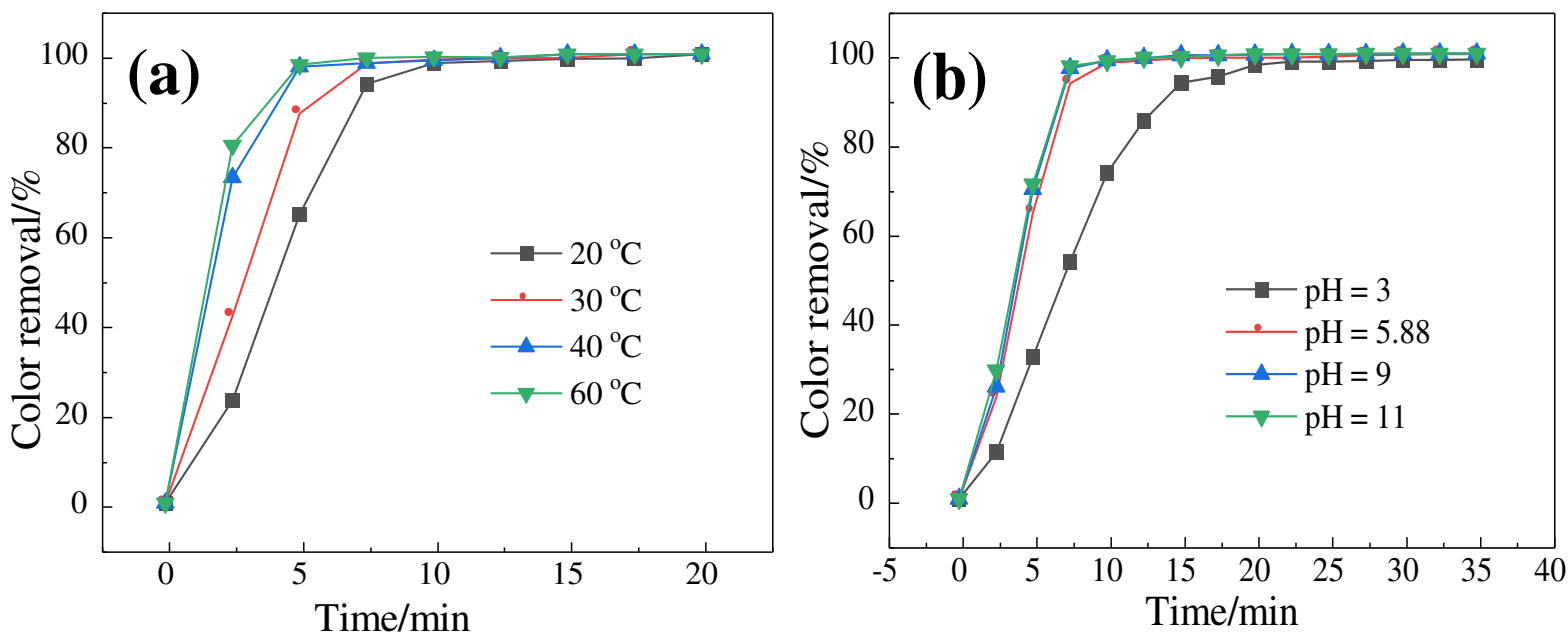

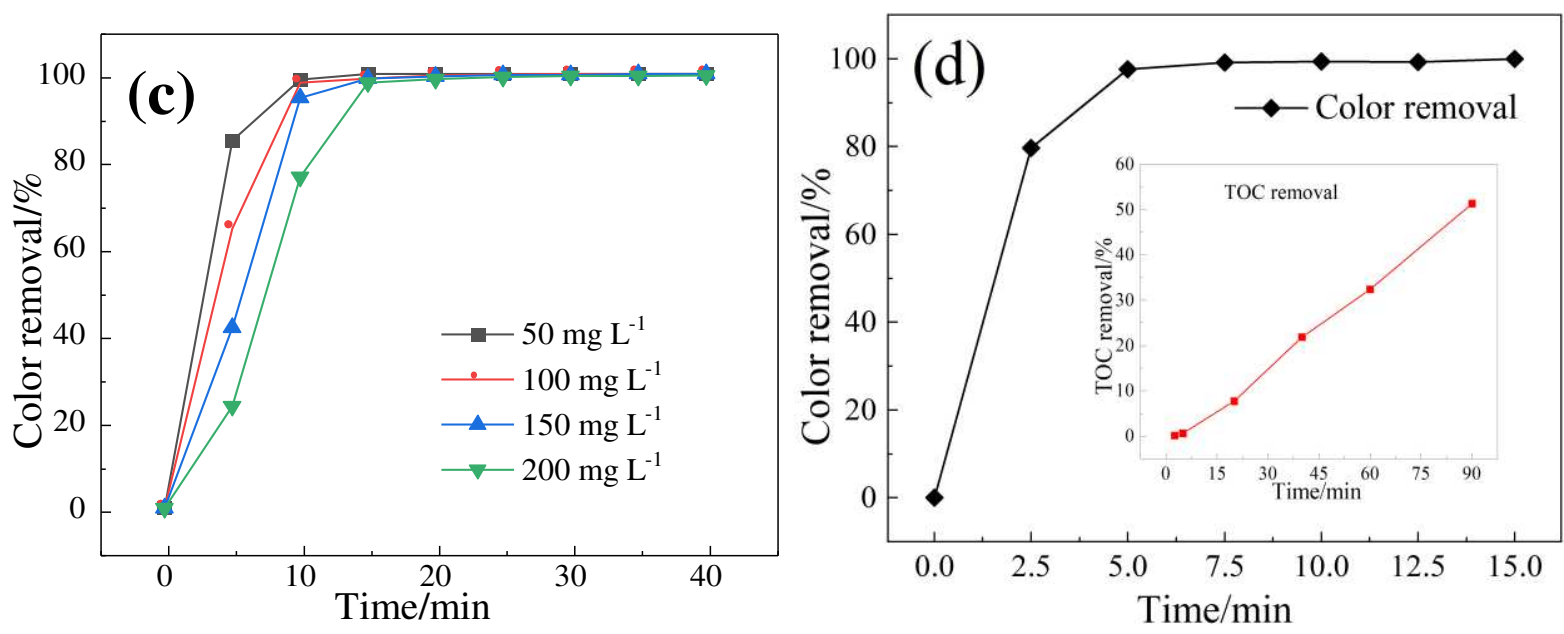

Fig. 4 Effect of temperatures on color removal rate (a), conditions: ([RR24] $=50 \mathrm{mg} \mathrm{L}^{-1} ; j=45 \mathrm{~mA} \mathrm{~cm}^{-2}$; process, which is convenient and energy-saving. 


\subsubsection{The effects of different initial pH}

\subsubsection{Effect of the initial concentration of RR24}

Fig.4c shows the different initial concentrations of 50-200 mg L-1 of RR24 on the decolorization efficiency. At 15 min, the decolorization efficiency of RR24 was $99.91 \%, 98.94 \%$, and $97.98 \%$, respectively, which decreased with the increase of its initial concentration, but the overall decolorization efficiency was excellent. In the electrolysis process, $\ln \left(\mathrm{A}_{0} / \mathrm{A}_{\mathrm{t}}\right)$ - $\mathrm{t}$ satisfies the pseudo-first-order kinetic relationship; At $50 \mathrm{mg} \mathrm{L}^{-1}$ and $100 \mathrm{mg} \mathrm{L}^{-1}$, the apparent kinetic constants are close, $0.52 \mathrm{~min}^{-1}$ and $0.50 \mathrm{~min}^{-1}$, respectively. Under the same other conditions, the amount of $\bullet \mathrm{OH}$ produced on the electrode surface is certain; As the initial concentration increases, the concentration of radicals is diluted, and the probability of collision with dye molecules decreases, and the entire electrochemical oxidation process turns into diffusion control, which reduces the decolorization 
rate. Within a certain range, the amount of $\bullet \mathrm{OH}$ on the surface of BDD is constant. The higher the initial concentration of RR24, the more the number of $-\mathrm{N}=\mathrm{N}$ - fractured simultaneously, the subsequent accumulation of intermediate products will inevitably require more free radical which prolonged degradation time increased energy consumption. Therefore, the initial concentration is $100 \mathrm{mg} \mathrm{L}^{-1}$.

\subsection{Energy consumption and Mineralization} selected treatment method has greater advantages compared with other methods, as shown in Table 2 .

Table 2 Different treatment technologies on RR24

\begin{tabular}{|c|c|c|c|c|c|c|c|c|}
\hline \multirow[b]{2}{*}{ Technology } & \multirow[b]{2}{*}{ Means } & \multicolumn{3}{|c|}{ Degradation parameter } & \multicolumn{2}{|c|}{ Removal/\% } & \multirow[b]{2}{*}{$\begin{array}{c}\text { Other } \\
\text { parameter }\end{array}$} & \multirow[b]{2}{*}{ Ref. } \\
\hline & & $\begin{array}{c}\mathrm{C}_{0} \\
\left(\mathrm{mg} \mathrm{L}^{-1}\right)\end{array}$ & $\begin{array}{l}\text { Time } \\
(\min )\end{array}$ & $\mathrm{C}_{\mathrm{e}}$ & Color & Organic & & \\
\hline Photocatalysis & $\begin{array}{c}0.75 \mathrm{~g} \mathrm{~L}^{-1} \\
\mathrm{TiO}_{2}\end{array}$ & 10 & 60 & - & 88.69 & $\begin{array}{l}\mathrm{TOC}= \\
17.78\end{array}$ & - & $\begin{array}{l}\text { (Zhu et al., } \\
\text { 2013) }\end{array}$ \\
\hline Photocatalysis & $\begin{array}{l}1.0 \mathrm{~g} \mathrm{~L}^{-1} \\
\mathrm{ZrW}_{11} \mathrm{Sn}\end{array}$ & 8 & 240 & - & 45.1 & - & - & (Feng, 2015) \\
\hline $\begin{array}{l}\text { Electrocoagulati } \\
\text { on }\end{array}$ & $\begin{array}{c}\mathrm{Al} \\
\text { electrodes }\end{array}$ & 100 & 35 & $\begin{array}{c}2.5 \mathrm{~g} \mathrm{~L}^{-1} \\
\mathrm{NaCl}\end{array}$ & 97.9 & $\begin{array}{c}\mathrm{COD}= \\
83.8\end{array}$ & - & $\begin{array}{l}\text { (Abu Ghalwa } \\
\text { et al., 2015) }\end{array}$ \\
\hline Adsorption & $\begin{array}{c}1.0 \mathrm{~g} \mathrm{~L}^{-1} \\
\text { SBB-ZnO3 }\end{array}$ & 250 & 60 & - & 42.1 & - & $\begin{array}{c}\mathrm{q}_{\max }=105.2 \\
\mathrm{mg} \mathrm{g}^{-1}\end{array}$ & $\begin{array}{l}\text { (Van et al., } \\
\text { 2021) }\end{array}$ \\
\hline $\mathrm{EO}-\mathrm{NO}_{3}{ }^{-} / \mathrm{SO}_{4}{ }^{2-}$ & Ti/BDD & 100 & 90 & $\begin{array}{l}100 \mathrm{mM} \\
\mathrm{Na}_{2} \mathrm{SO}_{4}\end{array}$ & 100 & $\begin{array}{l}\mathrm{TOC}= \\
51.35\end{array}$ & $\begin{array}{l}E_{c}=0.92 \\
\mathrm{kWh} \mathrm{m}^{-3}\end{array}$ & In this paper \\
\hline
\end{tabular}




\subsection{The relative contribution of different active species}

TBA and $\mathrm{MeOH}$ are used as scavengers for $\bullet \mathrm{OH}$ and $\mathrm{SO}_{4^{\bullet}}{ }^{-}$(Zhang et al., 2013). Methanol can remove $\bullet$ $\mathrm{OH}$ and $\mathrm{SO}_{4}{ }^{--}$very quickly, but TBA is relatively inert to $\mathrm{SO}_{4}{ }^{-}$(Kamagate et al., 2018). Similarly, phenol can also remove $\bullet \mathrm{OH}, \mathrm{SO}_{4} \bullet^{-}$and $\mathrm{NO}_{3} \cdot$. As shown in Fig. 5a, 5b, and 5c, TBA, $\mathrm{MeOH}$, and phenol all have a great inhibitory effect on the decolorization efficiency of RR24, showing that $\bullet \mathrm{OH}$ is the main active substance in the degradation and decolorization of $\mathrm{RR} 24$, while the direct effect of $\mathrm{NO}_{3} \cdot$ and $\mathrm{SO}_{4}{ }^{\bullet}$ is negligible, the system mainly relies on the oxidation of $\bullet \mathrm{OH}$. The addition of phenol almost directly oxidizes RR24 at the electrode, showing that direct electron transfer (DET) contribution in this system is minimal. By analyzing the apparent kinetic constants, the relative contribution of different active species to the decolorization of RR24 can be estimated. After processing the data with pseudo-first-order kinetics (Fig. 5d. and Table 3), results show that the contribution rate of $\bullet \mathrm{OH}$ reached $99.47 \%$. In other words, the addition of $\mathrm{NO}_{3}{ }^{-}$, act as a catalytic agent, greatly improves the production of $\cdot \mathrm{OH}$ in the $\mathrm{EO}-\mathrm{NO}_{3}{ }^{-} / \mathrm{SO}_{4}{ }^{2-}$.
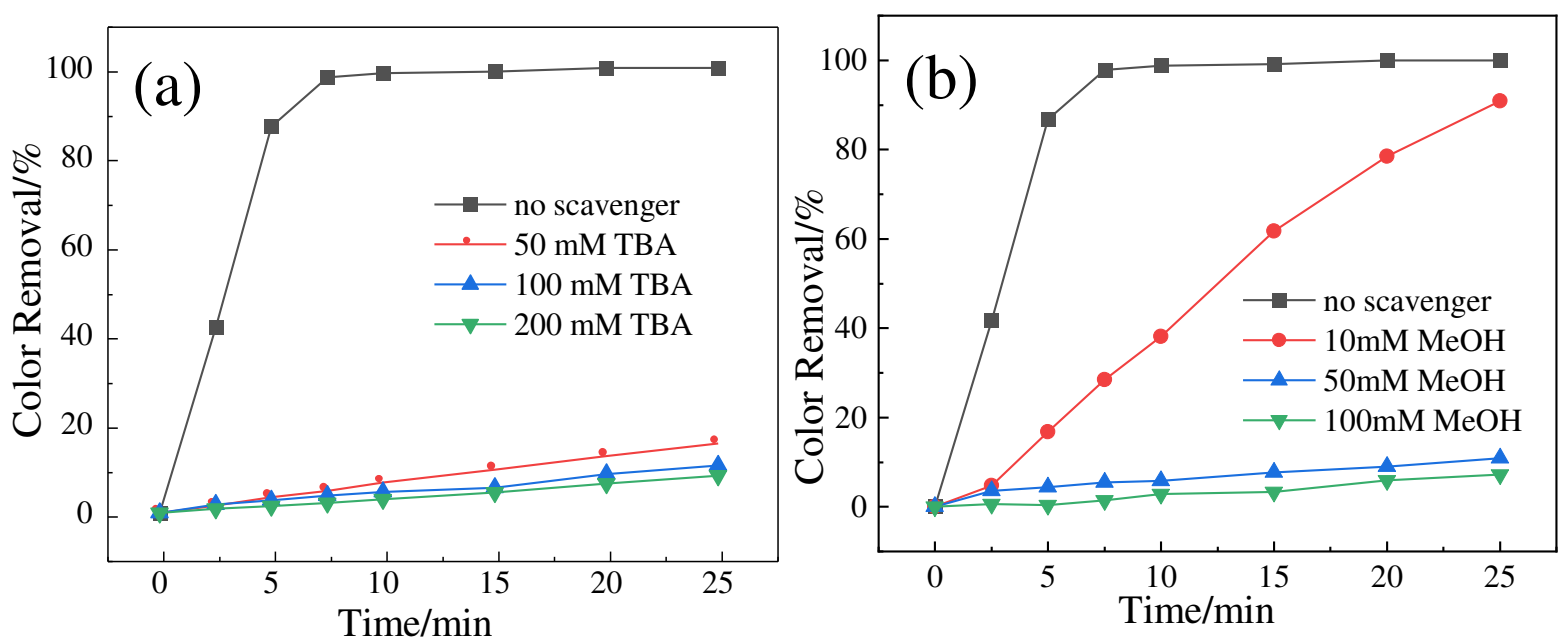

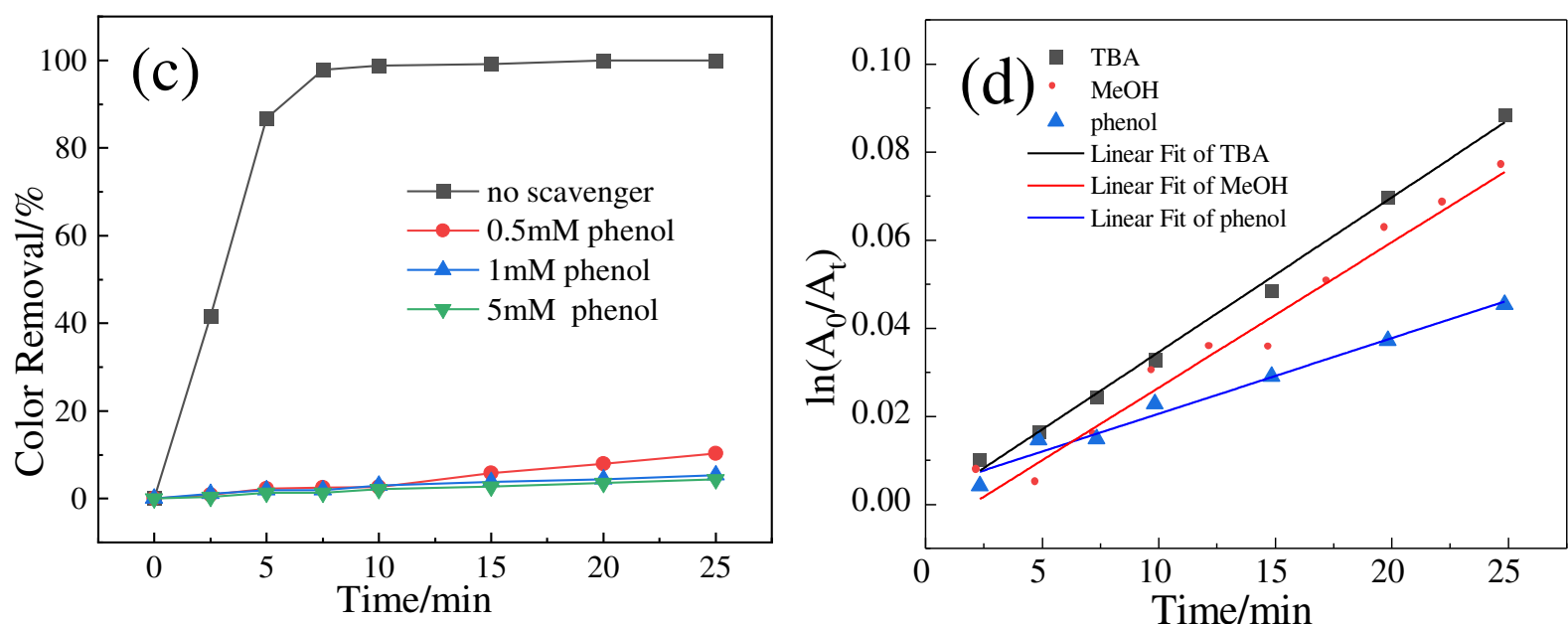

Fig.5. Different free radical quenchers to RR24 decolorization rate curve with time: TBA (a), $\mathrm{MeOH}$ (b),

phenol (c) and its $\ln \left(\mathrm{A}_{0} / \mathrm{A}_{\mathrm{t}}\right)-\mathrm{t}$ relationship (d);([RR24] $=100 \mathrm{mg} \mathrm{L}^{-1} ; \mathrm{j}=45 \mathrm{~mA} \mathrm{~cm}{ }^{-2} ;\left[\mathrm{Na}_{2} \mathrm{SO}_{4}\right]=100 \mathrm{mM}$;

Table 3 Rate constants and contribution rates of different active species

\begin{tabular}{|c|c|c|c|c|}
\hline & Active species & $k$ & $\mathrm{R}^{2}$ & Contribution rate \\
\hline none & $\mathrm{DET}+\bullet \cdot \mathrm{OH}+\mathrm{SO}_{4} \bullet-+\mathrm{NO}_{3} \bullet$ & 0.6596 & 0.99 & $100 \%$ \\
\hline TBA & $\mathrm{DET}+\mathrm{SO}_{4} \cdot{ }^{\bullet-}+\mathrm{NO}_{3} \bullet$ & 0.0035 & 0.99 & \\
\hline $\mathrm{MeOH}$ & $\mathrm{DET}+\mathrm{NO}_{3} \bullet$ & 0.0033 & 0.97 & \\
\hline \multirow[t]{4}{*}{ phenol } & DET & 0.0017 & 0.97 & $0.26 \%$ \\
\hline & $\bullet \mathrm{OH}$ & 0.6561 & & $99.47 \%$ \\
\hline & $\mathrm{NO}_{3} \cdot$ & 0.0016 & & $0.24 \%$ \\
\hline & $\mathrm{SO}_{4}{ }^{--}$ & 0.0002 & & $0.03 \%$ \\
\hline
\end{tabular}




\subsection{RR24 degradation pathway}

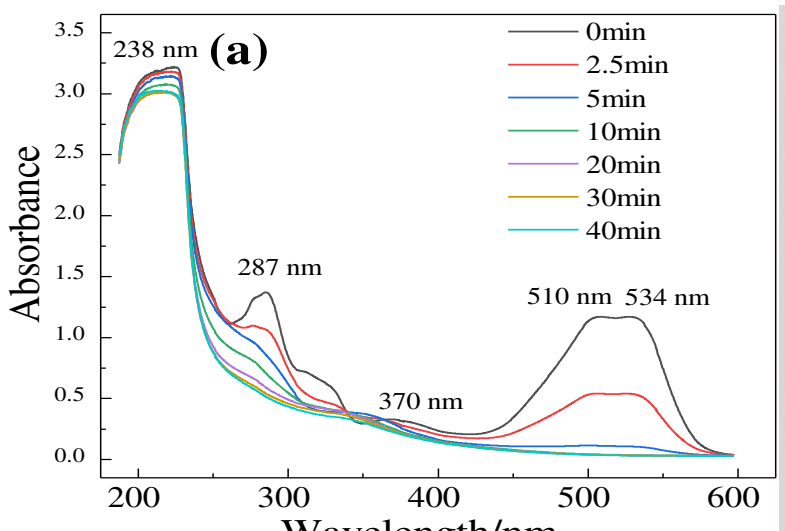

(b)

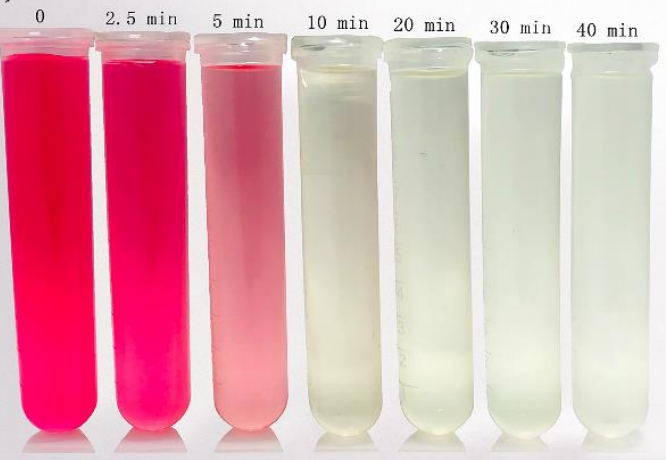

Wavelength $/ \mathrm{nm}$

Fig. 6. RR24 UV-Vis full spectrum under different degradation time conditions (a), the color of RR24 under

different degradation time (b), conditions: $\left([\mathrm{RR} 24]=100 \mathrm{mg} \mathrm{L}^{-1} ; \mathrm{j}=45 \mathrm{~mA} \mathrm{~cm}{ }^{-2} ;\left[\mathrm{Na}_{2} \mathrm{SO}_{4}\right]=100 \mathrm{mM}\right.$;

$\left[\mathrm{NaNO}_{3}\right]=7 \mathrm{mM}$; original $\left.\mathrm{pH} ; 60^{\circ} \mathrm{C}\right)$

The UV-Vis spectra at different electrolysis times (Fig. 6a) shows that after $2.5 \mathrm{~min}$ of reaction, the absorption peaks at $510 \mathrm{~nm}$ and $534 \mathrm{~nm}$ are significantly reduced, the naphthalene ring absorption peaks at 370 $\mathrm{nm}$ are reduced, and the benzene ring absorption peaks at $238 \mathrm{~nm}$ and $287 \mathrm{~nm}$ are dropping slightly. After 10 min, the characteristic absorption peaks at $510 \mathrm{~nm}$ and $534 \mathrm{~nm}$ disappeared completely, and the conjugated chromonic system containing azo bonds in the RR24 molecule was destroyed and decolorized. In the ultraviolet region, the benzene ring absorption peak at $287 \mathrm{~nm}$ and the naphthalene ring absorption peak at $370 \mathrm{~nm}$ disappeared, leaving only the benzene ring absorption peak at $238 \mathrm{~nm}$. The results show that in a short reaction time, EAOP can rapidly degrade the azo group and naphthalene ring in the dye wastewater into benzene ring products, and finally be oxidized to $\mathrm{CO}_{2}$ and $\mathrm{H}_{2} \mathrm{O}$. 


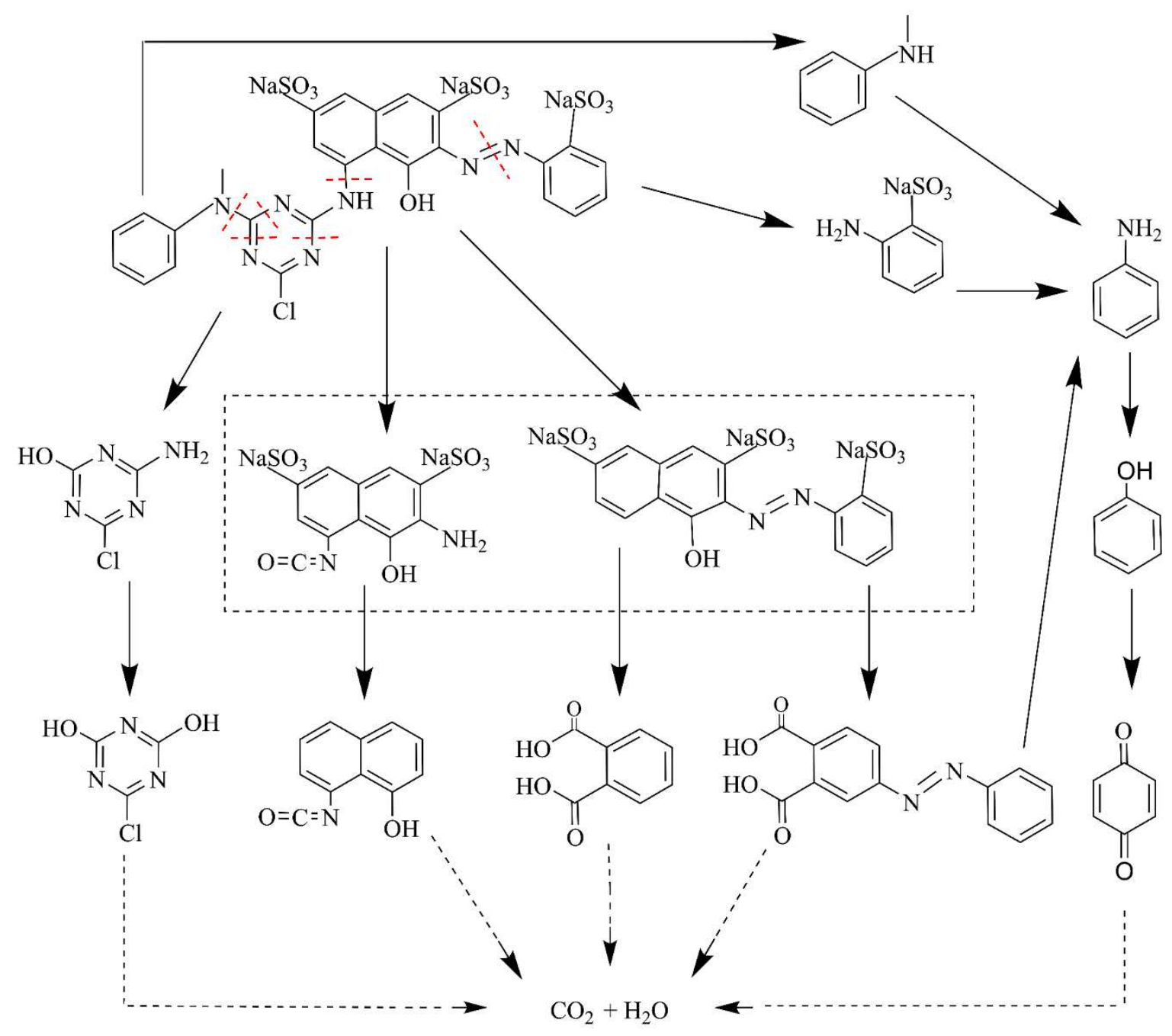

Fig.7. The proposed degradation pathways of RR24. Possible intermediate products are marked with a dotted

box.

The degradation pathways of the RR24 molecule can be judged by the intermediate product obtained by

LC-MS, including 2,4-(benzodiazepine) phthalic acid, 1-isocyanate-naphthalene, phthalic acid, N-methylaniline, aniline, benzoquinone, phenol, 6-chloro-1,3,5-triazine-2,4-diol, 4-amino-6-chloro-1,3,5-triazin-2-ol, nitrate, and sulfate ions. Table SM-2 and Figure SM-2 have the mass spectrum data of the above products. Figure 7 shows the proposed degradation pathways of RR24. The azo bond break first, then the cleavage of the C-N bond between the benzene or naphthalene rings and the triazine ring, followed by the $\mathrm{C}-\mathrm{N}$ bond between the 
amide and the amide group and the naphthalene or triazine rings (Xikui Wang et al., 2011). The triazine compound is oxidized further to 6-chloro-1,3,5-triazine-2,4-diol, 4-amino-6-chloro-1,3,5-triazin-2-ol and the amino converted to a hydroxyl group. Aniline compounds are turned into phenolic compounds, oxidized to benzoquinone, and finally oxidized to $\mathrm{CO}_{2}$ and $\mathrm{H}_{2} \mathrm{O}$ (Ruiz et al., 2011; Asghar et al., 2015). Naphthalene compounds are converted into 2, 4-(benzodiazepine) phthalic acid, and 1-isocyanate naphthalene; forming sulfate ions through the sulfonic acid group cut from the naphthalene ring, and finally the nitrogen in the RR24 molecule is oxidized to nitrate ion (Thiam et al., 2016).

\section{Conclusion}

First, for high-efficiency decolorization and degradation, the $\mathrm{NO}_{3}{ }^{-}+\mathrm{SO}_{4}{ }^{2-}$ system is determined to be a suitable electrochemical system for RR24 degradation by comparing the oxidative degradation systems of different electrolytes. Secondly, the effect of several operating parameters on RR24 decolorization is discussed. Among them, the current density and $\mathrm{NO}_{3}{ }^{-}$concentration have the greatest impact. The best operating process parameters for RR24 electrochemical degradation are obtained: current density $45 \mathrm{~mA} \mathrm{~cm}{ }^{-2}, 100 \mathrm{mM}$ support electrolyte, $7 \mathrm{mM} \mathrm{NO}_{3}{ }^{-}$, at $60^{\circ} \mathrm{C}$, initial $\mathrm{pH}$ is not adjusted, and $\mathrm{RR} 24$ initial concentration $100 \mathrm{mg} \mathrm{L}^{-1}$. Under this condition, the energy consumption for $100 \%$ decolorization within 15 min was $0.92 \mathrm{kWh} \mathrm{m}^{-3}$, and the TOC reached $51.35 \%$ within $90 \mathrm{~min}$. The quencher on the decolorization of RR24 electrochemical decolorization was also studied. It was found that $\bullet \mathrm{OH}$ was closely related to the decolorization degradation of RR24, reaching a contribution rate of $99.47 \%$. Finally, the samples were scanned by UV-Vis at different electrolysis times, and LC-MS tested the samples after 40 min of electrolysis to deduce the possible degradation route of RR4 by analyzing the intermediate products in the degradation process. To achieve higher dye wastewater treatment efficiency, the $\mathrm{EO} / \mathrm{NO}_{3}{ }^{-}+\mathrm{SO}_{4}{ }^{2-}$ system can perform advanced treatment on the effluent after biological treatment 

source added.

Declarations

\section{Ethics approval and consent to participate}

Not applicable

\section{Competing interests}

The authors declare that they have no competing interests.

\section{Funding}

The authors declare that they have no known competing financial interests.

\section{Author Agreement}

The specific work of each author in this study was as follows:

Yining Tang: Writing- Reviewing and Editing, Deliang He: Supervision, Yanni Guo: Supervision, Jun

Liu Mengli: Investigation.

and approved its submission to the journal of 'Environmental Science and Pollution Research'.

\section{Acknowledgements}

The authors would like to thank Zhou yuan from Shiyanjia Lab (www.shiyanjia.com) for the HPLC-MS analysis.

\section{Availability of data and materials' statement}

All data generated or analysed during this study are included in this published article and its supplementary 
Abu Ghalwa, M., N., Saqer, A.M., 2015. Removal of Reactive Red 24 Dye by Clean Electrocoagulation Process Using

Ammar, S., Abdelhedi, R., Flox, C., Arias, C., Brillas, E., 2006. Electrochemical degradation of the dye indigo carmine at boron-doped diamond anode for wastewaters remediation. Environ. Chem. Lett. 4, 229-233. http://doi.org/10.1007/s10311-006-0053-2

Asghar, A., Raman, A.A.A., Daud, W.M.A.W., 2015. Advanced oxidation processes for in-situ production of hydrogen peroxide/hydroxyl radical for textile wastewater treatment: a review. J. Cleaner Prod. 87, 826-838. http://doi.org/10.1016/j.jclepro.2014.09.010

Beck, F., Kaiser, W., Krohn, H., 2000. Boron doped diamond (BDD)-layers on titanium substrates as electrodes in applied electrochemistry. Electrochim. Acta. 45, 4691-4695. http://doi.org/10.1016/s0013-4686(00)00621-6

Brillas, E., Martinez-Huitle, C.A., 2015. Decontamination of wastewaters containing synthetic organic dyes by electrochemical methods. An updated review. Appl. Catal. B: Environ. 166, 603-643. http://doi.org/10.1016/j.apcatb.2014.11.016

Brito, C.N., Ferreira, M.B., de O. Marcionilio, S.M.L., de Moura Santos, E.C.M., Léon, J.J.L., Ganiyu, S.O., Martínez-Huitle, C.A., 2018. Electrochemical Oxidation of Acid Violet 7 Dye by Using Si/BDD and Nb/BDD Electrodes. J. Electrochem. Soc. 165, E250-E255. http://doi.org/10.1149/2.1111805jes

Buck, C., Skillen, N., Robertson, J., Robertson, P.K.J., 2018. Photocatalytic OH radical formation and quantification over $\mathrm{TiO}_{2}$ P25: Producing a robust and optimised screening method. Chinese Chem Lett 29, 773-777. http://doi.org/10.1016/j.cclet.2018.04.022 
Corona-Bautista, M., Picos-Benitez, A., Villasenor-Basulto, D., Bandala, E., Peralta-Hernandez, J.M., 2021.

Ding, J., Bu, L., Zhao, Q., Kabutey, F.T., Wei, L., Dionysiou, D.D., 2020. Electrochemical activation of persulfate on BDD and DSA anodes: Electrolyte influence, kinetics and mechanisms in the degradation of bisphenol A. J.

El-Ghenymy, A., Centellas, F., Rodríguez, R.M., Cabot, P.L., Garrido, J.A., Sirés, I., Brillas, E., 2015. Comparative use of anodic oxidation, electro-Fenton and photoelectro-Fenton with Pt or boron-doped diamond anode to decolorize and mineralize Malachite Green oxalate dye. Electrochim. Acta. 182, 247-256. http://doi.org/10.1016/j.electacta.2015.09.078

Feng, S., 2015. Photocatalytic Degradation of Simulated Dye Wastewater with Polyoxometalate/Titanium Dioxide Composite. School ofenvironmental and chemical engineering. Dalian Jiaotong University

Florenza, X., Solano, A.M.S., Centellas, F., Martinez-Huitle, C.A., Brillas, E., Garcia-Segura, S., 2014. Degradation of the azo dye Acid Red 1 by anodic oxidation and indirect electrochemical processes based on Fenton's reaction chemistry. Relationship between decolorization, mineralization and products. Electrochim. Acta. 142, 276-288. http://doi.org/10.1016/j.electacta.2014.07.117

Gandini, D., Mahe, E., Michaud, P.A., Haenni, W., Perret, A., Comninellis, C., 2000. Oxidation of carboxylic acids at boron-doped diamond electrodes for wastewater treatment. $\quad$ J. Appl. Electrochem. $\quad 30, \quad 1345-1350$. http://doi.org/10.1023/a:1026526729357

Garcia-Segura, S., Lanzarini-Lopes, M., Hristovski, K., Westerhoff, P., 2018. Electrocatalytic reduction of nitrate: Fundamentals to full-scale water treatment applications. Appl. Catal. B: Environ. 236, 546-568. http://doi.org/10.1016/j.apcatb.2018.05.041 
He, Y., Huang, W., Chen, R., Zhang, W., Lin, H., Li, H., 2015. Anodic oxidation of aspirin on PbO 2 , BDD and porous Ti/BDD electrodes: Mechanism, kinetics and utilization rate. Sep. Purif. Technol. 156, 124-131. http://doi.org/10.1016/j.seppur.2015.09.036

He, Y., Lin, H., Guo, Z., Zhang, W., Li, H., Huang, W., 2019. Recent developments and advances in boron-doped http://doi.org/10.1016/j.seppur.2018.11.056

Kamagate, M., Amin Assadi, A., Kone, T., Coulibaly, L., Hanna, K., 2018. Activation of persulfate by irradiated laterite for removal of fluoroquinolones in multi-component systems. J. Hazard. Mater. 346, 159-166. http://doi.org/10.1016/j.jhazmat.2017.12.011

Kuchtova, G., Chylkova, J., Vana, J., Vojs, M., Dusek, L., 2020. Electro-oxidative decolorization and treatment of model wastewater containing Acid Blue 80 on boron doped diamond and platinum anodes. J. Electroanal. Chem. 863. http://doi.org/10.1016/j.jelechem.2020.114036

Li, W., Liu, G., Miao, D., Li, Z., Chen, Y., Gao, X., Liu, T., Wei, Q., Ma, L., Zhou, K., Yu, Z., 2020. Electrochemical oxidation of Reactive Blue 19 on boron-doped diamond anode with different supporting electrolyte. J. Environ. Chem. Eng. 8. http://doi.org/10.1016/j.jece.2020.103997

Li, X., Tang, S., Yuan, D., Tang, J., Zhang, C., Li, N., Rao, Y., 2019. Improved degradation of anthraquinone dye by electrochemical activation of PDS. Ecotoxicol. Environ. Saf. 177, 77-85. http://doi.org/10.1016/j.ecoenv.2019.04.015

Liang, C., Wang, Z.S., Bruell, C.J., 2007. Influence of $\mathrm{pH}$ on persulfate oxidation of TCE at ambient temperatures. Chemosphere. 66, 106-113. http://doi.org/10.1016/j.chemosphere.2006.05.026

Louit, G., Foley, S., Cabillic, J., Coffigny, H., Taran, F., Valleix, A., Renault, J.P., Pin, S., 2005. The reaction of coumarin with the $\mathrm{OH}$ radical revisited: hydroxylation product analysis determined by fluorescence and 

Degradation Using a Boron-doped Diamond Electrode and Enhanced by Zeolite- $\mathrm{TiO}_{2}$ Photocatalyst. Int. J. Electrochem. Sci., 5904-5922. http://doi.org/10.20964/2018.06.45

Medrano-Rodríguez, F., Picos-Benítez, A., Brillas, E., Bandala, E.R., Pérez, T., Peralta-Hernández, J.M., 2020. Electrochemical advanced oxidation discoloration and removal of three brown diazo dyes used in the tannery industry. J. Electroanal. Chem. 873. http://doi.org/10.1016/j.jelechem.2020.114360

Miao, D., Liu, G., Wei, Q., Hu, N., Zheng, K., Zhu, C., Liu, T., Zhou, K., Yu, Z., Ma, L., 2020. Electro-activated persulfate oxidation of malachite green by boron-doped diamond (BDD) anode: effect of degradation process parameters. Water Sci. Technol. 81, 925-935. http://doi.org/10.2166/wst.2020.176

Moussa, D.T., El-Naas, M.H., Nasser, M., Al-Marri, M.J., 2017. A comprehensive review of electrocoagulation for water treatment: Potentials and challenges. J. Environ. Manage. 186, 24-41. http://doi.org/10.1016/j.jenvman.2016.10.032

Nidheesh, P.V., Zhou, M., Oturan, M.A., 2018. An overview on the removal of synthetic dyes from water by electrochemical advanced oxidation processes. Chemosphere. 197, 210-227. http://doi.org/10.1016/j.chemosphere.2017.12.195

Palma-Goyes, R.E., Guzman-Duque, F.L., Penuela, G., Gonzalez, I., Nava, J.L., Torres-Palma, R.A., 2010. Electrochemical degradation of crystal violet with BDD electrodes: effect of electrochemical parameters and identification of $\quad$ organic $\quad$ by-products. $\quad$ Chemosphere. http://doi.org/10.1016/j.chemosphere.2010.07.020

Panakoulias, T., Kalatzis, P., Kalderis, D., Katsaounis, A., 2010. Electrochemical degradation of Reactive Red 120 using DSA and BDD anodes. J. Appl. Electrochem. 40, 1759-1765. http://doi.org/10.1007/s10800-010-0138-2 
Panizza, M., Cerisola, G., 2005. Application of diamond electrodes to electrochemical processes. Electrochim. Acta.

Panizza, M., Michaud, P.A., Cerisola, G., Comninellis, C., 2001. Anodic oxidation of 2-naphthol at boron-doped diamond electrodes. J. Electroanal. Chem. 507, 206-214. https://doi.org/10.1016/S0022-0728(01)00398-9

Ruiz, E.J., Arias, C., Brillas, E., Hernandez-Ramirez, A., Peralta-Hernandez, J.M., 2011. Mineralization of Acid 
Umschlag, T., Zellner, R., Herrmann, H., 2002. Laser-based studies of $\mathrm{NO}_{3}$ radical reactions with selected aromatic compounds in aqueous solution. Phys. Chem. Chem. Phys. 4, 2975-2982. http://doi.org/10.1039/B110263J

Uranga-Flores, A., de la Rosa-Juarez, C., Gutierrez-Granados, S., de Moura, D.C., Martinez-Huitle, C.A., Hernandez, J.M.P., 2015. Electrochemical promotion of strong oxidants to degrade Acid Red 211: Effect of supporting electrolytes. J. Electroanal. Chem. 738, 84-91. http://doi.org/10.1016/j.jelechem.2014.11.030 
Xiang, Q., Yu, J., Wong, P.K., 2011. Quantitative characterization of hydroxyl radicals produced by various photocatalysts. J Colloid Interface Sci 357, 163-167. http://doi.org/10.1016/j.jcis.2011.01.093

Xikui Wang, Yuechang Wei, Chen Wang, Weilin Guo, Jingang Wang, Jiang, J., 2011. Ultrasonic degradation of reactive brilliant red $\mathrm{K}-2 \mathrm{BP}$ in water with $\mathrm{CCl}_{4}$ enhancementPerformance optimization and degradation mechanism. Sep. Purif. Technol. 81, 69-76. http://doi.org/10.1016/j.seppur.2011.07.003

Zhang, J., Shao, X., Shi, C., Yang, S., 2013. Decolorization of Acid Orange 7 with peroxymonosulfate oxidation catalyzed by granular activated carbon. Chem. Eng. J. 232, 259-265. http://doi.org/10.1016/j.cej.2013.07.108 


\section{Supplementary Files}

This is a list of supplementary files associated with this preprint. Click to download.

- SupplementaryMaterial.docx 